\title{
Jewels in the crown: a century of achievement for the Journal of Neurology, Neurosurgery \& Psychiatry
}

\author{
Matthew C Kiernan ${ }^{1,2}$
}

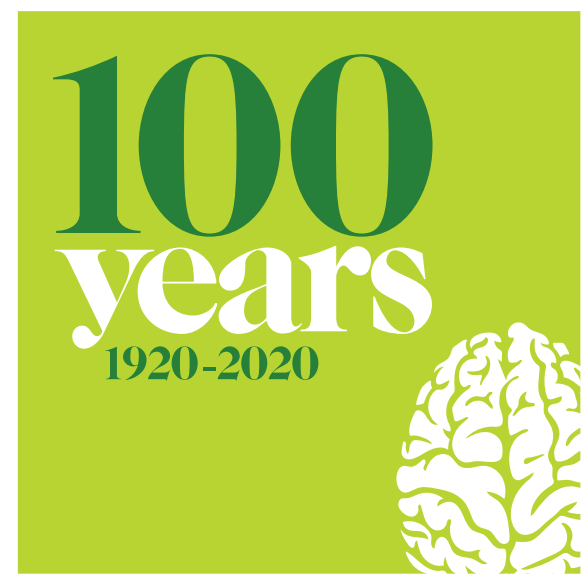

Centenary of key narratives in clinical neuroscience

Welcome to 2020 - a year in which the Journal of Neurology, Neurosurgery and Psychiatry reaches its century. It would be interesting to jump into the time machine, to turn back the clock to 1920 and ask the foundation editor, Kinnier Wilson, what he anticipated when he launched the journal. On reflection, it would seem difficult to predict the astounding advancements in clinical neuroscience to which the past century has borne witness. No doubt Kinnier Wilson would have been proud of the many contributions the JNNP has made and the citation classics it has generated over that time. How could he have predicted the path his journal would forge-from understanding the circuitry of memory, ${ }^{1}$ unlocking disease pathophysiology, ${ }^{23}$ the creation of rating scales (some with citation counts $>48000$ to date) ${ }^{4}$ the role of neurosurgery, ${ }^{5}$ to the advent of new therapies, ${ }^{6}$ comprehending quality of life, ${ }^{7}$ addressing patient outcomes ${ }^{8}$ and establishing disease criteria. ${ }^{9}$ These mere samples in the phenomenal history of the journal mark the beginning of critical

${ }^{1}$ Bushell Chair of Neurology, Brain and Mind Centre, University of Sydney, Sydney, New South Wales, Australia

${ }^{2}$ Neurology, Royal Prince Alfred Hospital, Camperdown, New South Wales, Australia

Correspondence to Professor Matthew C Kiernan, Bushell Chair of Neurology, Brain and Mind Centre, University of Sydney, Sydney, NSW 2040, Australia; matthew.kiernan@sydney.edu.au breakthroughs in clinical neuroscience that we now take for granted. Papers such as these, and many more trailblazing articles from the vault, will feature in the journal throughout this centenary year in our novel series of 2020 Visions.

History tells us that it would have been impossible for the JNNP's first editor to anticipate the pace of progress across technologies in neuroscience, ranging from molecular and imaging advances to a proliferation of hardware and software capabilities. However, over those 100 years it has been these breakthrough developments that have given researchers and clinicians the power to gain a more profound understanding of the human brain, the processes of thought and the ability to interrogate human personality. What then would Kinnier Wilson have made of the journal's personality - a quiet achiever? Not prone to fanfare? Unconventional at times, and ready to move with progress? Most likely, all of the above, and much more.

Turning to the future, what might we anticipate about the brain and mind, about neurology, neurosurgery and psychiatry, as the next century of publications dawns? Here, the notion of big data is certainly of interest, with the human brain exposed to the equivalent of 34 gigabytes of information per day-a quantity that would overload a humble laptop within a week. Rising to that challenge, human cognition will necessarily evolve, along with ways to fine-tune brain circuitry. Indeed, over recent decades, crucial developments in cognitive neuroscience have led to the advent of noninvasive functional imaging techniques, including functional MRI. Through geographically identifying regions of the brain that are operational during thought and by measuring blood flow changes in relation to neural activity, we are uncovering the deepest workings of the brain and mind. When nerve cells are activated by cognitive tasks, they consume oxygen and the local response to this oxygen utilisation is an increase in blood flow to regions of increased neural activity. It has only been through adaptation of core neurophysiological techniques, combined with imaging, that information about such intricate brain functions has become clearer to the modern clinician. This combination of clinical and functional techniques, along with highly evolved neuroimaging methods, is being utilised to explore higher cortical function, from emotional processing through to behaviour. This in turn is providing insight into how the brain processes signals and prepares actions. Perhaps, through interpretation and analysis of this functional activity, we may soon be able to touch the Holy Grail of neuroscience-the mystery of consciousness.

In the decades to come, there will continue to be a clear focus on the development of portable systems for investigation of the mind, for devices to monitor brain behaviour and seemingly to boost the power of brain performance. With the advent of nanotechnology, there is also the distinct prospect of reducing the cumbersome nature of imaging systems, with complex machinery reduced to nano-sized proportions. Imagine the prospect of bypassing damaged brain cells to regain normal function. And, one step further, imagine the possibilities of the intriguing developments in cortical processing and the creation of effective brain-computer interfaces. Such bridges between biology and technology will translate volitional thought processes into signals capable of driving an external world. The new external realm of the brain awaits.

These and many other as-yet inconceivable developments will change the face of neuroscience into the next century, with the inevitable advancements in drug nanodelivery systems, genetic therapies, ultrasound delivery of directed therapy across the blood brain barrier and brain regenerative projects leading the way. It is in this fast-moving and ever-changing landscape that JNNP will be liberal in its coverage, ${ }^{10-17}$ striving to honour the inquisitive, collaborative and broadminded legacy of Kinnier Wilson ${ }^{18}{ }^{19}$ what he would have described as a pure and tangible impact. ${ }^{20}$ 
Twitter Matthew C Kiernan @jnnp_bmj

Funding The author has not declared a specific grant for this research from any funding agency in the public, commercial or not-for-profit sectors.

Competing interests None declared.

Patient consent for publication Not required

Provenance and peer review Commissioned; internally peer reviewed.

(C) Author(s) (or their employer(s)) 2020. No commercial re-use. See rights and permissions. Published by BMJ.

D Check for updates

To cite Kiernan MC. J Neurol Neurosurg Psychiatry 2020;91:1-2

Received 14 November 2019

Accepted 14 November 2019

J Neurol Neurosurg Psychiatry 2020;91:1-2.

doi:10.1136/jnnp-2019-322443

\section{REFERENCES}

1 Scoville WB, Milner B. Loss of recent memory after bilateral hippocampal lesions. J Neurol Neurosurg Psychiatry 1957;20:11-21.

2 Hughes AJ, Daniel SE, Kilford L, et al. Accuracy of clinical diagnosis of idiopathic Parkinson's disease: a clinico-pathological study of 100 cases. J Neurol Neurosurg Psychiatry 1992;55:181-4.

3 Gibb WR, Lees AJ. The relevance of the Lewy body to the pathogenesis of idiopathic Parkinson's disease. $J$ Neurol Neurosurg Psychiatry 1988;51:745-52.

4 Hamilton M. A rating scale for depression. J Neurol Neurosurg Psychiatry 1960;23:56-62.

5 Simpson D. The recurrence of intracranial meningiomas after surgical treatment. J Neurol Neurosurg Psychiatry 1957:20:22-39.

6 Francis PT, Palmer AM, Snape M, et al. The cholinergic hypothesis of Alzheimer's disease: a review of progress. J Neurol Neurosurg Psychiatry 1999;66:137-47.

7 Schrag A, Jahanshahi M, Quinn N. What contributes to quality of life in patients with Parkinson's disease? J Neurol Neurosurg Psychiatry 2000;69:308-12.

8 Jennett B, Snoek J, Bond MR, et al. Disability after severe head injury: observations on the use of the Glasgow outcome scale. J Neurol Neurosurg Psychiatry 1981;44:285-93.

9 Brun A, Englund B, Gustafson L. Clinical and neuropathological criteria for frontotemporal dementia. The Lund and Manchester groups. J Neurol Neurosurg Psychiatry 1994;57:416-8.

10 Lai KSP, Liu CS, Rau A, et al. Peripheral inflammatory markers in Alzheimer's disease: a systematic review and meta-analysis of 175 studies. J Neurol Neurosurg Psychiatry 2017:88:876-82.
11 Eisen A, Braak H, Del Tredici K, et al. Cortical influences drive amyotrophic lateral sclerosis. J Neurol Neurosurg Psychiatry 2017;88:917-24.

12 Kawachi I, Lassmann H. Neurodegeneration in multiple sclerosis and neuromyelitis optica. J Neurol Neurosurg Psychiatry 2017:88:137-45.

13 Banerjee G, Carare R, Cordonnier C, et al. The increasing impact of cerebral amyloid angiopathy: essential new insights for clinical practice. J Neurol Neurosurg Psychiatry 2017:88:982-94.

14 Uncini A, Shahrizaila N, Kuwabara S. Zika virus infection and Guillain-Barré syndrome: a review focused on clinical and electrophysiological subtypes. $J$ Neurol Neurosurg Psychiatry 2017;88:266-71.

15 Lappin JM, Darke S, Farrell M. Stroke and methamphetamine use in young adults: a review. J Neurol Neurosurg Psychiatry 2017:88:1079-91.

16 Mollan SP, Davies B, Silver NC, et al. Idiopathic intracranial hypertension: consensus guidelines on management. J Neurol Neurosurg Psychiatry 2018;89:1088-100

17 Garg N, Park SB, Vucic S, et al. Differentiating lower motor neuron syndromes. J Neurol Neurosurg Psychiatry 2017;88:474-83.

18 Kiernan MC. The realm of neurology. J Neurol Neurosurg Psychiatry 2011;82:1.

19 Kiernan MC. The realm of neurology--past, present and future. J Neurol Neurosurg Psychiatry 2011:82:1.

20 Kiernan MC. What is impact? I Neurol Neurosurg Psychiatry 2012:83:1-2. 